\title{
A dynamic look at narrative change in psychotherapy: A case study tracking innovative moments and protonarratives using state space grids
}

\author{
ANTÓNIO P. RIBEIRO ${ }^{1}$, TIAGO BENTO ${ }^{2}$, JOÃO SALGADO ${ }^{2}$, WILLIAM B. STILES ${ }^{3}, \&$ \\ MIGUEL M. GONÇALVES ${ }^{1}$ \\ ${ }^{1}$ School of Psychology, University of Minho, Braga, Portugal; ${ }^{2}$ Research Center at the Center for Cognitive-Behavioral Studies \\ and Intervention, ISMAI, Maia, Portugal E ${ }^{3}$ Miami University, Department of Psychology, Oxford, Ohio, USA
}

(Received 9 March 2010; Revision received 24 May 2010; accepted 18 fune 2010)

\begin{abstract}
This study aims to further the understanding of how innovative moments (IMs), which are exceptions to a client's problematic self-narrative in the therapy dialogue, progress to the construction of a new self-narrative, leading to successful psychotherapy. The authors' research strategy involved tracking IMs, and the themes expressed therein (or protonarratives), and analysing the dynamic relation between IMs and protonarratives within and across sessions using state space grids in a good-outcome case of constructivist psychotherapy. The concept of protonarrative helped explain how IMs transform a problematic self-narrative into a new, more flexible, self-narrative. The increased flexibility of the new self-narrative was manifested as an increase in the diversity of IM types and of protonarratives. Results suggest that new self-narratives may develop through the elaboration of protonarratives present in IMs, yielding an organizing framework that is more flexible than the problematic self-narrative.
\end{abstract}

Keywords: process research; narrative; innovative moments; protonarratives

This special issue assumes that human beings construct meaning from the ongoing flow of experiences in the form of self-narratives (Bruner, 1986; Hermans \& Hermans-Jansen, 1995; McAdams, 1993; Polkinghorne, 1988; Sarbin, 1986; White, 2007; White \& Epston, 1990; see also Dimaggio, Salvatore, Azzara, Catania, Semerari, et al., 2003, for a review of this topic). Self-narratives can be viewed as rules of action and worldviews that "play a vital self-organizing function for the individual" (Neimeyer, Herrero, \& Botella, 2006, p. 129), preventing psychological chaos and allowing a sense of self (Dimaggio, Salvatore, Azzara, Catania, Semerari, et al., 2003; Neimeyer, 1995), or as meaning bridges, giving smooth access to a person's diverse experiences and self-states (Osatuke et al., 2004).

Self-narratives can become problematic when they restrict cognitive and affective diversity, thus limiting behavioral possibilities. For instance, depressive clients often organize their self-narratives around the themes of loss, inability, and hopelessness, thus preventing other possible themes from being constructed (O. F. Gonçalves \& Machado, 1999). We present a conceptualization of how problematic selfnarratives can be replaced by alternative, more flexible, self-narratives in successful psychotherapy and a case study that highlights this process of narrative change.

\section{Innovative Moments}

Significant changes in a client's problematic selfnarrative, such as those that occur in successful psychotherapy, start with the emergence of novelty, which White and Epston (1990) called "unique outcomes" and we call "innovative moments"

Correspondence concerning this article should be addressed to Miguel M. Gonçalves, University of Minho, School of Psychology, 4710 Braga, Portugal. E-mail: mgoncalves@psi.uminho.pt 
(IMs; also called "i-moments" in previous publications; M. M. Gonçalves, Matos, \& Santos, 2009; Matos, Santos, M. M. Gonçalves, \& Martins, 2009). IMs can be conceived as exceptions to the problematic rules that organize a client's life. For instance, if the rules that organize the self-narrative of a depressive client are lack of assertion and feelings of inability, then an exception to these rules in the form of an assertive thought, action, or feeling would be considered an IM (see M. M. Gonçalves, Santos, et al., 2010). This study aimed to examine how IMs led to the construction of a new self-narrative in a successful psychotherapy.

Previous research has shown that IMs can be reliably identified using the innovative moments coding system (IMCS; M. M. Gonçalves, Ribeiro, Matos, Mendes, \& Santos, 2010a, 2010b), and that IMs occur in different kinds of brief therapy, namely narrative (Matos et al., 2009; Santos, M. M. Gonçalves, \& Matos, 2010; Santos, M. M. Gonçalves, Matos, \& Salvatore, 2009), emotionfocused (M. M. Gonçalves, Mendes, Ribeiro, Angus, \& Greenberg, 2010; Mendes, Ribeiro, Angus, Greenberg, Sousa, \& M. M. Gonçalves, in press), client-centered (M. M. Gonçalves, Mendes, et al., 2010), and constructivist (Ribeiro, M. M. Gonçalves, \& Ribeiro, 2009; Ribeiro, M. M. Gonçalves, \& Santos, in press) therapies, thus representing a pattern of change common to several different approaches. The IMCS distinguishes five different IM categories. IMs may contain both client and therapist turn-taking, insofar as change is understood to be co-constructed between therapist and client (Angus, Levitt, \& Hardtke, 1999). In the following, we give a definition of each IM, along with an illustrative clinical vignette. To aid comparisons, we constructed all vignettes for a hypothetical client diagnosed with major depression with severe social withdrawal.

1. Action IMs: specific behaviors that challenge the problematic self-narrative.

Client: Yesterday, I went to the cinema for the first time in months!

2. Reflection IMs: thoughts, feelings, intentions, projects, or other cognitive products that challenge the problematic self-narrative.

Client: I realize that the more I isolate myself, the more depression gets overwhelming.

3. Protest IMs: new behaviors (like action IMs) and/or thoughts (like reflection IMs) that challenge the problematic self-narrative, representing a refusal of its assumptions. This active refusal is the key feature that allows distinguishing protest from action and reflection.

Client: I'm feeling stronger now and won't let depression rule my life anymore! I want to experience life, I want to grow, and it feels good to be in charge of my own life.

4. Reconceptualization IMs: the most complex type of innovation in which the client not only describes some form of contrast between present and past (e.g., "Now I've changed $X$ or $Y$ ") but also understands the processes that allowed this transformation.

Client: You know ... when I was there at the museum, I thought to myself, "You really are different ... A year ago you wouldn't be able to go to the supermarket!" Ever since I started going out, I started feeling less depressed ... it is also related to our conversations and changing jobs.

Therapist: How did you have this idea of going to the museum?

Client: I called my Dad and told him, "We're going out today!"

Therapist: This is new, isn't it?

5. Performing change IMs: new aims, experiences, activities, or projects, anticipated or in action, as a consequence of change.

Therapist: You seem to have so many projects for the future now!

Client: Yes, you're right. I want to do all the things that were impossible for me to do while I was dominated by depression. I want to work again and to have the time to enjoy my life with my children. I want to have friends again. The loss of all the friendships of the past is something that still hurts me really deeply. I want to have friends again, to have people to talk to, to share experiences, and to feel the complicity in my life again.

Findings from IM research using quantitative, qualitative, and mixed methods, including both hypothesis-testing studies with samples and intensive case studies, suggest that there is a common pattern of change across different therapeutic approaches. Poorand good-outcome cases tend to be similar in the beginning of the therapeutic process, presenting IMs of action, reflection, and protest. However, by the 
middle of the process, good-outcome cases present a relatively greater salience (i.e., a larger percentage of time during sessions) in reconceptualization and performing change IMs. In fact, reconceptualization and performing change IMs are almost absent in poor-outcome cases (Matos et al., 2009; Mendes et al., in press; Santos et al., 2009, 2010; Ribeiro et al., 2009, in press; see M. M. Gonçalves, Santos, et al., 2010, for a review).

Based on these studies, a heuristic model of narrative change in psychotherapy was developed (M. M. Gonçalves et al., 2009; see Figure I), according to which change starts with action and reflection IMs. These are considered the most elementary kind of novelty, in which the person starts wondering about how life could be different (reflection IMs), which may instigate new actions (action IMs) congruent with these reflections (or vice versa, from action to reflection). Several cycles of action and reflection (or, inversely, reflection and action) may be needed to ensure, to the person and to significant others, that something really different from the problematic self-narrative is happening.

Sometimes protest IMs emerge alongside action and reflection IMs at the beginning of therapy, while other times protest IMs emerge only after some development of reflection and action IMs. Protest IMs represent a client's objection to the problematic self-narrative's assumptions, allowing the client to reposition him- or herself toward the problem and toward significant others who may support it. By protesting, the client assumes a position of assertiveness, empowerment, and agency in the process of self-reconstruction.

In successful therapies, reconceptualization emerges around the middle of the therapeutic process. Reconceptualization's two ingredients - contrast between present and past and reflective understanding of the process of change - both appear important in sustaining meaningful change. First, the contrast between past and present integrates material that emerged in the more episodic IMs that occurred before (action, reflection, and protest). Second, reflective understanding of the process of change positions the client as an active author of the change process insofar as the novelty was not just something that happened but was something that the client was responsible for. This component of reconceptualization involves a metaposition (see Dimaggio, Salvatore, Azzara, \& Catania, 2003), which seems to be vital in the process of change. The reconceptualization, following cycles of action, reflection, and protest IMs, builds a new narrative of the self, which may compete with the problematic self-narrative. Performing change IMs eventually emerge, representing the generalization of the new narrative into different life areas.

\section{Protonarratives}

Theoretically, each IM involves the emergence of divergent narrative content or a theme that contrasts with the dominant, problematic self-narrative. In the course of the therapeutic process, some of these innovative contents recur frequently. We propose to identify such recurrent contents or themes as protonarratives. ${ }^{1}$ Whereas IMs (e.g., action, reflection) are types of narrative processes, protonarratives are the specific contents that emerge in a client's IMs.

As an illustration, consider the process of change in a hypothetical client's problematic self-narrative centered on the lack of assertiveness. Initially, IMs might be focused on (1) acknowledging the client's needs, (2) being assertive, or (3) expressing anger toward those who neglected the client's needs over time (e.g., his or her parents) and avoiding contact with them. All three represent exceptions to the problematic self-narrative (lack of assertion). Suppose we observe recurrent IMs focused on expressing anger. The redundancy around this theme may be understood as the emergence of a resentment protonarrative. The resentment protonarrative might emerge in several types of IMs, from action to performing change. This protonarrative could be transitory, giving way to a new one centered on the client accepting that others did their best and trying to establish a new kind of relationship with them by asserting his or her needs; this is an acceptance

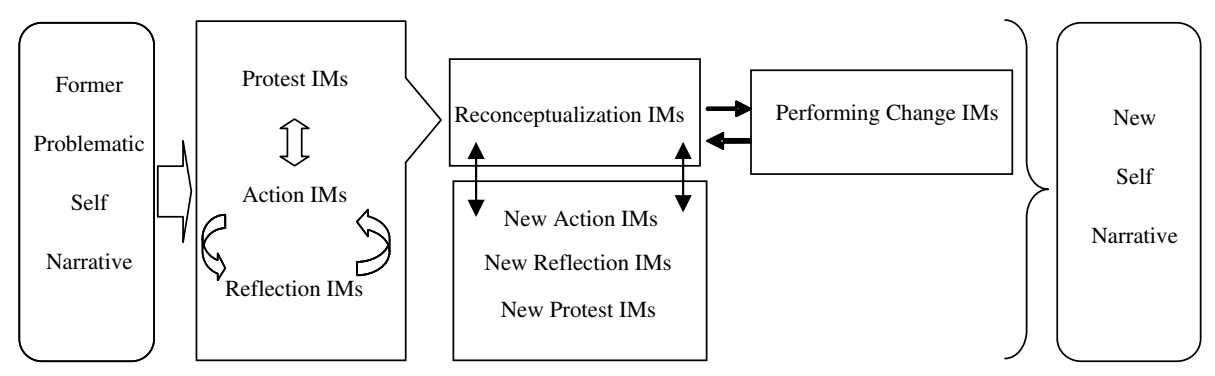

Figure I. Heuristic model of narrative change. IM, innovative moment. (From Narrative therapy and the nature of "innovative moments" in the construction of change by M. M. Gonçalves, M. Matos, \& A. Santos, 2009. Adapted with permission.) 
protonarrative. If the acceptance protonarrative expanded and became dominant in the client's life, it could be considered as a new self-narrative.

Protonarratives contain elements of new potential self-narratives insofar as they may be considered as comprising a new set of rules (e.g., "Instead of privileging other people's wishes, I should respect my own wishes"). Thus, they represent the specific content of the change that a client's IMs promote. As the prior example illustrates, not all protonarratives become stable or viable. Some become stronger (e.g., the acceptance protonarrative), while others fade away (e.g., the resentment protonarrative). Progress toward a new self-narrative may be indicated by IMs shifting from one recurrent protonarrative (e.g., resentment) to another (e.g., acceptance).

As IMs occur during the therapeutic conversation, facilitated by different therapeutic techniques (e.g., empty chair in emotion-focused therapy; externalization in narrative therapy), they make the corresponding protonarratives available for elaboration. In the course of the therapeutic conversation following an IM, the protonarratives become more detailed; the possible meanings and implications become clearer. In turn, this fosters the occurrence of new IMs and the exploration of new cognitive, emotional, and behavioral possibilities.

Both protonarratives and IMs can be identified and classified in the therapeutic dialogue. To us, combining these two sorts of measurement seemed a promising research strategy to develop an understanding of the change process. Therefore, we have adopted a research strategy that involved (1) tracking IMs, (2) tracking alternative protonarratives, and (3) analyzing the dynamic relations between IM types and protonarratives during the therapeutic process (Ribeiro, Bento, M. M. Gonçalves, \& Salgado, 2010).

Theoretically, increase in diversity in types of IMs and protonarratives across the sessions is consistent with successful change, because flexibility is considered a central characteristic of the meaning-making processes involved in the alternative self-narrative construction. Rigidity of these processes would cause stability and dominance of certain meanings over other possible ones, consequently blocking their emergence and expansion (White \& Epston, 1990).

\section{State Space Grids}

To analyze the development of IMs and protonarratives and their dynamic interactions across therapy sessions, we used state space grids (SSGs; Lewis, Lamey, \& Douglas, 1999; Lewis, Zimmerman, Hollenstein, \& Lamey, 2004). SSGs are a means of data analysis proposed in the context of developmental psychology for the study of two synchronized time series of categorical or ordinal variables (Lewis et al., 1999, 2004).

In constructing SSGs, two time series are considered to constitute a dynamic system (Thelen \& Smith, 1998) with a finite number of possible states. The system's state at a given moment in time is defined by the positions of the two variables that constitute the system. The system's complete range of possible states is called state space, which can be represented by a matrix in which categories of one variable are represented on the $x$-axis and categories of the second variable are represented on the $y$-axis. Each cell in the matrix then corresponds to one of the system's possible states. Although a wide range of states is possible, systems typically occupy only a limited number within a given time interval. Systems tend to persevere and stabilize in certain states, and these more frequent and recurrent states are called attractors. Attractors may be characterized as "absorbing" or "pulling" states (Granic \& Hollenstein, 2003) or as pushing the system away from other possible states.

Research using SSGs has focused on dyadic interaction between infants and caregivers (e.g., Granic \& Lamey, 2002; Granic, Hollenstein, Dishion, \& Patterson, 2003; Granic, O'Hara, Pepler, \& Lewis, 2007; Hollenstein, Granic, Stoolmiller, \& Snyder, 2004; Hollenstein \& Lewis, 2006), adolescent friendship (Dishion, Nelson, Winter, \& Bullock, 2004), emotional system of married couples (Gardner \& Wampler, 2008), and social dynamics in the preschool (Granic \& Hollenstein, 2003; Martin, Fables, Hanish, \& Hollenstein, 2005; see Hollenstein, 2007, for a review). We applied SSGs in a single-case design, reasoning that "individual time course data can facilitate movement beyond the question of whether change occurs and toward an understanding of how change occurs (Barkham, Stiles, \& Shapiro, 1993)" (Hayes, Laurenceau, Feldman, Strauss, \& Cardaciotto, 2007, p. 717).

\section{The Present Study}

The present study set out to map self-narrative reconstruction in a good-outcome case. We used SSGs, a new methodology in this area, to track the emergence of alternative protonarratives in IMs and to depict their development across the therapeutic process, seeking a richer understanding of how narrative change occurs. We considered this as a theory-building case study (Stiles, 2005, 2009), in which we examined the fit between case observations and our theory, aiming to refine our model of change by adjusting it to accommodate new observations. We explored four main research questions: 
How do IM types and salience evolve across sessions (narrative process)?

Which protonarratives emerge in IMs, and how does their salience evolve across sessions (narrative content or theme)?

How are IM types (narrative process) associated with protonarratives across sessions (narrative content or theme)?

How does the flexibility of the alternative selfnarrative evolve across sessions?

\section{Method}

\section{Client}

Caroline (a pseudonym) was a 20-year-old White woman who gave permission for her materials to be used for research. She reported as her main problems feelings of sadness, hopelessness, and worthlessness after her entrance in the university and beginning a romantic relationship, which impaired her interpersonal relationships and her academic functioning. She described difficulties with being assertive (especially with her boyfriend), satisfying the needs of others to the detriment of her own. She usually took responsibility for her parents' problems, trying to protect her mother from her father, who used to stalk her even after divorce. During therapy, Caroline was able to make connections between these different problems and realize how they were all part of a larger functioning pattern: pessimism.

Caroline was diagnosed with an adaptation disorder with depressive symptoms, according to the Diagnostic and Statistical Manual of Mental Disorders (fourth edition; American Psychiatric Association, 1994). At the end of therapy, Caroline's was considered a good-outcome case on the basis of significant symptomatic change, as evidenced by her pre-post Outcome Questionnaire-45 (OQ-45.2; Lambert et al., 1996; Portuguese version adapted by Machado \& Klein, 2006) total score: Her pretherapy OQ-45 total score of 99 dropped to 50 at therapy termination. A reliable change index (RCI) analysis of her OQ-45 pre-post change scores classified Caroline as having met the criteria for recovery (i.e., a OQ-45 cutoff score of 67.82 and RCI criteria; Machado \& Fassnacht, 2010) at treatment termination (see Jacobson \& Truax, 1991; McGlinchey, Atkins, \& Jacobson, 2002).

\section{Therapy and Therapist}

Caroline participated in brief and individual constructivist therapy focused on implicative dilemmas (Fernandes, 2007; Fernandes, Senra, \& Feixas, 2009; Senra, Feixas, \& Fernandes, 2007) for 12 sessions as well as one follow-up session at her university's clinic. Therapy terminated by mutual decision after completion of the treatment manual, when Caroline and her therapist agreed that the main goals had been achieved. Video recordings were made of all 12 sessions. However, Sessions 1 and 11 failed to record because of technical problems, leaving 10 sessions available for analysis.

According to Senra and Ribeiro (2009), "Implicative dilemmas represent a form of blockage in the individual's constructing activity, where an undesired construction is strongly related to other, positive and self-defining, construction(s). As a result, the person can't move towards a desired construction as that would imply abandoning some nuclear features of the self, or embracing some undesired aspects that correlate with the wanted one" (p. 1). Senra et al. (2007; see also Fernandes, 2007) developed a brief therapy aimed at solving these impasses in client constructions, organized in five stages: (1) assessment, (2) reframing the problem as a dilemma, (3) dilemma elaboration, (4) alternative enactment, and (5) treatment termination. Sessions are structured in terms of goals and tasks, but there is time flexibility for their completion. Their proposal adopts a hermeneutic and phenomenological perspective, using predominantly explorative interventions, privileging reflection and elaboration of the client's personal meanings.

The therapist was a 25 year-old White female doctoral student in clinical psychology, with 3 years of prior clinical experience as psychotherapist, who had undergone training in the therapeutic model before participation in the study and attended weekly group supervision for this case.

\section{Researchers}

The qualitative IM analysis was conducted by António P. Ribeiro and two volunteer judges. All three were doctoral students in clinical psychology, and all were well versed in the IMCS (M. M. Gonçalves, Ribeiro, et al., 2010a, 2010b). The protonarrative analysis was conducted via discussions between António P. Ribeiro and the IMs research team. Miguel M. Gonçalves, a university faculty member in clinical psychology and Ribeiro's advisor, served as an auditor of protonarrative identification, reviewing and checking the judgments made by the team. Tiago Bento, a doctoral student in clinical psychology, and João Salgado, a university faculty member in clinical psychology, conducted the analysis of SSGs. William B. Stiles, a university faculty member in clinical psychology and Ribeiro's co-advisor, contributed to conceptualizing and writing this report. 


\section{Procedure}

Our research strategy involved three major steps of analysis: (1) identifying IMs, (2) identifying protonarratives, and (3) depicting and explaining the relations between these protonarratives and IMs during Caroline's therapy.

Identifying IMs: coding procedures and reliability. Session recordings were coded according to the IMCS (M. M. Gonçalves, Ribeiro, et al., 2010a, 2010b) by three judges: Judge 1 (António P. Ribeiro) coded all the sessions available (10 sessions); and Judges 2 and 3 (who were unaware of the outcomes) independently coded five sessions each. Before beginning their independent coding, the judges discussed their understanding of the client's problems (problematic self-narrative). This step was guided by the question: "What is the central rule/ framework that organizes Caroline's suffering?" This discussion aimed to generate a consensual definition of the client's main self-narrative rules so that all could code the exceptions to the rules (IMs). Caroline's problematic self-narrative was characterized as the "pessimism" rule, that is, the idea that whatever efforts she would be engaged in would never achieve positive results, and that she was not worthy. As Caroline put it in the third session, "I see myself as a rather negativistic sort of person these days, always thinking the worst, and I don't trust myself that much." Keeping the pessimism rule in mind, judges coded IMs from the video, identifying the onset and offset of each to the nearest second.

We computed the salience of each of the five IM types (the percentage of time in the session devoted to that specific type of IM) as well as the mean salience of each type throughout the process. We also computed the overall salience of IMs as the total percentage of time in the session devoted to any of the five types (i.e., the sum of the salience of the five types of IMs) as well as the mean salience of IMs throughout the process.

Interjudge agreement on salience was calculated as the overlapping time identified by both judges (Judges 1 and 2 or Judges 1 and 3) divided by the total time identified by either judge (or, equivalently, twice the agreed time spent on IMs divided by the sum of IM saliences independently identified by the two judges).The agreement on overall IM salience was $84.1 \%$. Reliability of distinguishing IM type, assessed by Cohen's kappa, was .90, showing strong agreement between judges (Hill \& Lambert, 2004). Because of the high interjudge reliability, we based our analyses on the coding of Judge 1 .

Identifying Caroline's protonarratives: coding procedures and reliability. We analyzed each IM in sequence and described the underlying protonarrative. This step was guided by the question: "What is the potential counter-rule/framework of behaving (acts, thoughts, emotions) present in this IM?" or, in a different but equivalent formulation, "If this IM expands itself to a new self-narrative, what would be the rule that shapes this new self-narrative?" We tried to capture the answer to this question in the form of a sentence or a word. The protonarrative for each successive IM was then compared with the protonarratives previously described, looking for convergences and divergences. Whenever strong convergences were found, the new IM was understood as sharing the previously described protonarrative. When strong divergences were found, a new protonarrative was formulated to incorporate the new meanings.

During this process, the protonarratives constantly underwent modification to incorporate new IMs and were continually interrogated for coherence and explanatory capacity. This process ceased when the emergent protonarratives were dense and complex enough to capture all of the variations in the IMs. This procedure was inspired by the method of constant comparison, rooted in grounded theory analysis (Fassinger, 2005).

The procedure for coding protonarratives involved discussion between Ribeiro and the IM research team, which included anywhere from two to 12 individuals, as well as an auditing process (Hill et al., 2005), as described next.

Ribeiro worked independently and periodically presented his work to the research team. During these meetings, collaborators were invited to discuss the interpretation of the data. Whenever divergences were found, Ribeiro and the research team discussed the strengths of each other's interpretation and the criteria used to achieve them.

After the meetings, Ribeiro returned to independent work. He modified and improved his analysis, drawing on what he had learned at the meeting. Through this interactive procedure, strengths of each other were integrated, building consensus (Morrow, 2005; Schielke, Fishman, Osatuke, \& Stiles, 2009; Stiles, 2003).

Miguel M. Gonçalves served as an external auditor. His role was one of "questioning and critiquing: Does the organization of the categories make logical and conceptual sense? Is there another way of organizing the categories that better explicates the essence of the data?" (Hill et al., 2005, p. 201).

The salience of each protonarrative was computed for each session as the sum of the salience of IMs in which they emerged. We also computed the mean 
salience of each protonarrative throughout the process.

Illustrating the evolution of protonarratives with SSGs. We used SSGs (Lewis et al., 1999, 2004) to illustrate the evolution of Caroline's protonarratives and their relations with IMs across sessions.

In the graphic representations of SSGs, a system behavior across time is plotted as dots in the corresponding cells. When a new event takes place, another dot is added and a line that connects them is plotted to represent the direction of change. Thus, the system's evolution is plotted as a trajectory across the grid of cells that represent the system's possible states, yielding a two-dimensional topographic representation of the system's behavior during a given time interval. In this way, SSGs also offer quantification of this process, because a number of quantitative measures can be calculated from the graphic representation (see Results section), thereby bringing together quantitative and qualitative analysis. SSGs make it possible to focus simultaneously on content (because the states - the different cellsrepresent a given quality of the behavior or phenomenon under observation), structure (through the identification of attractors), and their unfolding through time.

To construct SSGs, we used GridWare, a software package developed by Lamey, Hollenstein, Lewis, and Granic (2004). A separate grid was constructed to depict the system's evolution within each of Caroline's psychotherapy sessions (see Figure II for an example of the grid constructed for Session 2). In each grid, three variables were plotted: two categorical variables (IM type [ $x$-axis: narrative process] and protonarrative type [ $y$-axis: narrative content or theme]) and one continuous variable (salience of each IM [represented by circle size]). Each circle in the grid characterizes an event as representing a state of the system, defined by an IM type and a protonarrative. The hollow circle represents the first IM in the session. Placement of the circles within

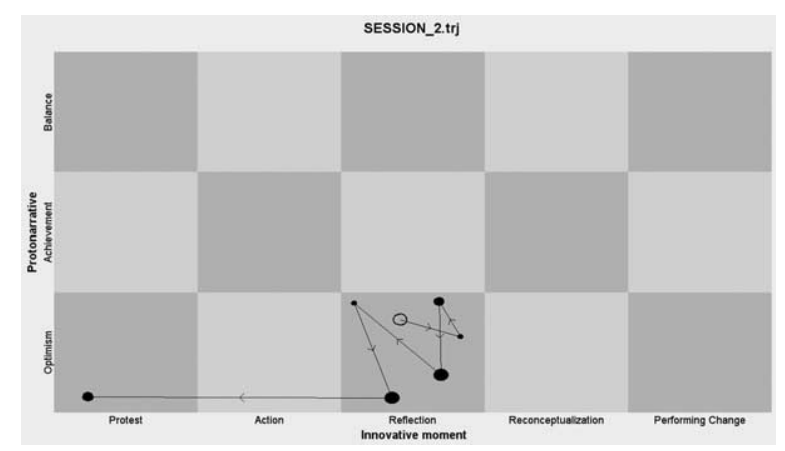

Figure II. Example of state space grid for Session 2. the cells is arbitrary; circles are arranged to allow representation of successive events of the same type. Lines represent transitions from one event to the next, and the arrows represent the direction of that transition.

To address the research question "How are IM types (narrative process) associated with protonarratives across session (narrative content or theme)?," grids were quantitatively analyzed to identify attractor regions (Lewis et al., 1999), that is, groups of events involving the same combination of IM types and protonarratives (criteria for identifying attractors are clarified in the Results section).

To pursue the research question "How does the flexibility of the alternative self-narrative, in terms of diversity in IMs and protonarratives, evolve across sessions?," a quantitative index of overall flexibility of the system (dispersion; Granic et al., 2007; Hollenstein \& Lewis, 2006) was computed (criteria for computing dispersion is clarified in the Results section).

\section{Results}

\section{How Do IM Types and Salience Evolve Across Sessions (Narrative Process)?}

Across the 10 sessions available for analysis, $26.84 \%$ of all the therapeutic conversation was devoted to IMs. This result is consistent with those from other good-outcome cases, in which the average overall salience of IMs is about $25 \%$ (e.g., Mendes et al., in press; Santos et al., 2009). The most common type of IM was reflection (15.6\%), followed by reconceptualization $(6.84 \%)$. Action occupied $2 \%$ of the entire therapy, and protest $(1.47 \%)$ and performing change $(0.93 \%)$ had relatively low salience. Examples of each type of IM are provided in Table I.

The total percentage of time devoted to IMs tended to increase as the treatment progressed, and the mixture of IMs changed (see Figure III). In the first five sessions, only reflection and protest IMs were present. Action emerged for the first time in Session 6 and was always present afterward. Reconceptualization emerged for the first time in Session 6 but had substantial salience only in the last three sessions. Likewise, performing change IMs were present in the last three sessions only (see Figure III).

Globally, these results corroborated the heuristic model of change summarized in Figure I (M. M. Gonçalves et al., 2009). That is, the overall salience of IMs increased throughout the process, and reflection and protest IMs progressed to reconceptualization and performing change IMs in the last sessions. 
Table I. Examples of Innovative Moments (Problematic Self-Narrative: Pessimism)

Innovative moment/content

Example

Action

New coping behaviours facing anticipated or existent obstacles Effective resolution of unsolved problem(s)

Active exploration of solutions

Restoring autonomy and self-control

Searching for information about the problem(s)

Reflection

Comprehension: reconsidering the problem(s)' causes and/or awareness of effects

New problem formulations

Adaptive self-instructions and thoughts

Intention to fight problem(s)' demands, references of self-worth and/or feelings of well-being

Reflecting about the therapeutic process

Considering the process and strategies; implemented to overcome the problem(s); references of self-worth and/or feelings of well-being (as consequences of change)

New positions: references to new/emergent identity versions in face of the problem(s)

Protest

Repositioning oneself toward the problem(s)

Positions of assertiveness and empowerment

\section{Reconceptualization}

These always involve two dimensions: description of the shift between two positions (past and present) and the process underlying this transformation

\footnotetext{
Performing change

Generalization into the future and other life dimensions of good outcomes

Problematic experience as a resource to new situations

Investment in new projects as a result of the process of change

Investment in new relationships as a result of the process of change

Performance of change: new skills

Reemergence of neglected or forgotten self-versions
}

C: I connected myself to the Internet and Ruth was there ... I told her: "I really have to study" and I disconnected.

T: Very good. You got to do what you could not do with your mother the other time.

C: Yes, I told her and then I disconnected ... we agreed it had to be like that ... It happened exactly, the same thing with my mother, she had something very important to tell me and I told her, "Wait for dinner time, Mum, I can't help you just now, I must do this now" and that's what I did ... I studied!

C: I would like to be optimistic, for I do believe that to be a great feature to live a better life.

C: I do not wish to be pessimistic, for I do not want to. I do not wish to live life with such dark, unfruitful eyes, for pessimism is indeed unfruitful after all!

C: I believe that our talks, our sessions, have proven fruitful, I felt like going back a bit to old times. It was good, I felt good, I felt it was worth it. And that's as I'm telling you: this effort that I made, all this hard work, something that I must improve yet, when I got to the exam I told myself, "At least you studied, you tried." I felt I was fighting for it, I was doing my utmost, working hard for something I really need ... I felt I was struggling, I was being able to put things in their right place, I felt I was fighting.

C: I thought I was not good company, because I was unhappy. I felt bad about myself and with myself and therefore I thought my misfortune would be passed on to others. It isn't so these days, so I moved away, you see, I tried to run from crowds, didn't feel like going to classes ... because it would be so full of people ... It isn't so these days. Nowadays I believe I am more receptive and, at the same time, I am receptive to that and I let myself go a little more to that as well, looking for people to talk with, go to the library, even for a little coffee, have a snack ... they are nice, opposite to what I often thought. They are nice and talk to me and worry about me.

Note. C, Caroline; T, therapist.

\section{Which Protonarratives Emerge in IMs and How Does Their Salience Evolve Across Sessions (Narrative Content or Theme)?}

Our qualitative analysis identified three protonarratives: optimism (mean salience $=15.77 \%$ ), achievement (mean salience $=4.29 \%$ ), and balance (mean salience $=6.98 \%$; see Table II for a summary). As shown in Figure IV, sessions differed with respect to the presence of protonarratives. Sessions 2 and 3 were characterized by only occasional instances of optimism exclusively. In Session 4 optimism and achievement were present, and in Session 5 only optimism was present again. In Sessions 6 and 7 the three protonarratives were present. In Sessions 8 and 9 two protonarratives were present again: optimism and achievement in Session 8 and achievement and 


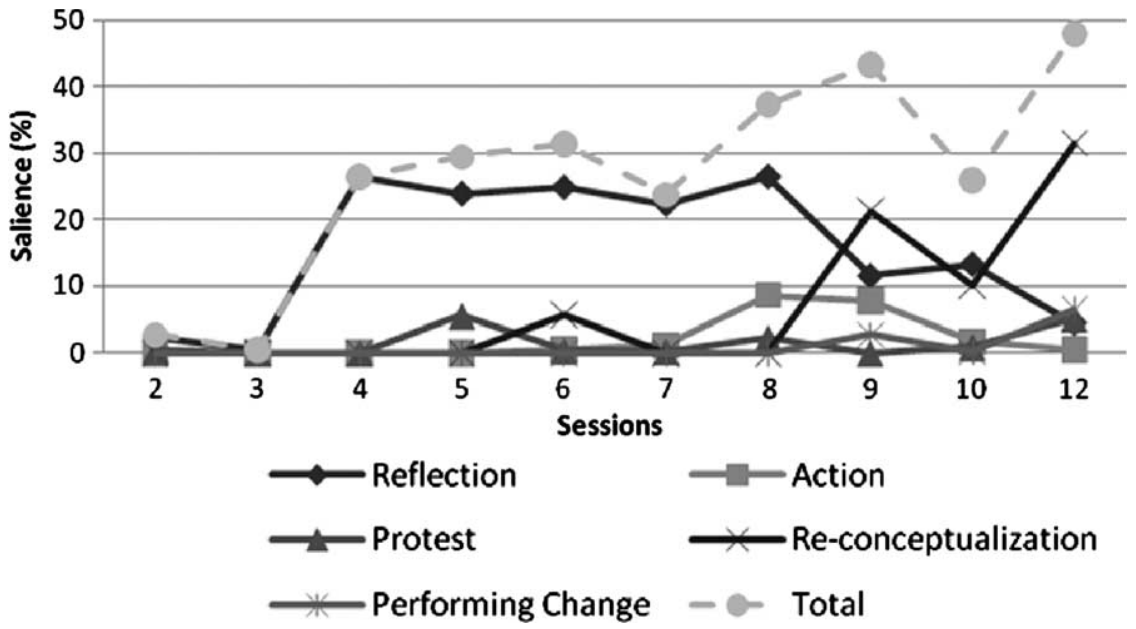

Figure III. Innovative moments salience throughout the process.

balance in Session 9. Sessions 10 and 12 were characterized by the presence of the three protonarratives again.

In more clinical terms, in much of her therapy, Caroline expressed a counter-rule, optimism, in relation to her current (problematic) rule or framework, pessimism. Up until Session 8, and again in Session 10, her IMs were mostly focused on the opposite of the problematic self-narrative, by centering her on the capacities she had shown in the past and her capacity to achieve change, as illustrated by her comment in Session 2: "Maybe I'll get what I want after all, I don't know." This IM content is the exact opposite of what she defined as the "pessimism" rule.

In Session 4, Caroline started to elaborate on new ways of dealing with her problems, leading to the emergence of a new protonarrative - achievement: "Well, I don't give up, you see, I keep on studying and realizing what my needs are ... this week, for instance, I was rather quiet, managed to study."

Table II. Protonarratives in Caroline's Case

\begin{tabular}{ll}
\hline Protonarrative & \multicolumn{1}{c}{ Contents } \\
\hline Optimism & $\begin{array}{l}\text { Life areas and/or capacities not dominated by } \\
\text { pessimism } \\
\text { Intention to overcome pessimism } \\
\text { Comprehension of pessimism causes }\end{array}$ \\
& $\begin{array}{l}\text { Awareness of pessimism effects } \\
\text { Strategies implemented to overcome } \\
\text { pessimism }\end{array}$ \\
Wchievement & $\begin{array}{l}\text { Well-being } \\
\text { Balanced relationship between pessimism and } \\
\text { optimism } \\
\text { Balanced relationship between own needs and } \\
\text { other's needs } \\
\text { Balanced relationship between study/work } \\
\text { and leisure }\end{array}$ \\
\hline
\end{tabular}

Later, in Session 6, a further protonarrative that proposed an equilibrium between pessimism and optimism emerged - balance: "I also believe that, sometimes, being pessimistic creates some kind of balance because if you are too optimistic, you start trusting yourself too much and you'll not strive."

Note that the problem (pessimism) was progressively integrated in these successive protonarratives. Optimism was a mere opposition of pessimism, achievement involved a more empowered relation with pessimism, and balance enabled a conditional movement between optimism and pessimism rather than a fixation on one of them. Thus, although our procedure distinguished these three as different protonarratives, they might also be considered as cumulative or as steps in a developmental sequence leading toward an alternative self-narrative.

\section{How Are IM Types (Narrative Process) Associated With Protonarratives Across Sessions (Narrative Content or Theme)?}

The SSGs shed light on the way Caroline's protonarratives evolved throughout the therapy. Figure $\mathrm{V}$ shows the 10 grids corresponding to Sessions 2 to 10 and Session 12 (the 10 sessions available for analysis). Also illustrated is the previously noted increase in the diversity of IMs (and their salience) and an increase in the diversity of protonarratives across treatment. Theoretically, diversity in types of IMs and protonarratives is consistent with successful change. As Caroline proceeded to explore each protonarrative, it occurred in progressively more types of IMs. At the same time, the exploration tended to give rise to new themes, leading to new protonarratives.

We identified attractors using the winnowing procedure developed by Lewis et al. (1999), which 


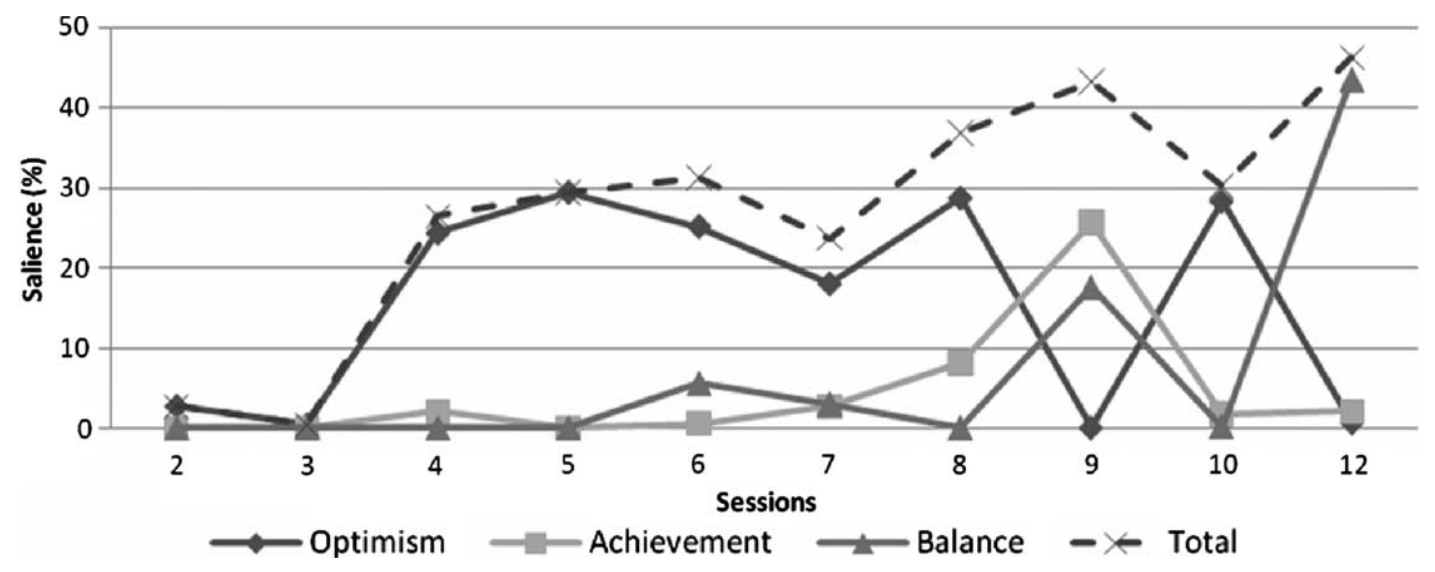

Figure IV. Protonarrative salience throughout the process.

defines an attractor as a cell or group of cells that accounts for $50 \%$ of grid heterogeneity. Heterogeneity is calculated first for each visited cell in the grid according the formula

$$
[(D / n)-d]^{2} /(D / n)
$$

where $d$ is the cell duration, $D$ is the total grid duration, and $n$ is the number of visited cells in the grid. Heterogeneity is then calculated for the entire grid according to the formula

$$
[n \Sigma(c) / n],
$$

where $c$ is each cell heterogeneity score and $n$ is the number of visited cells. The process is repeated, withdrawing from the analysis the cell with the lowest duration score at each round. The heterogeneity score for each round is then divided by the heterogeneity score for the entire grid. The process stops when the heterogeneity score drops below $50 \%$. Conceptually, attractors pinpoint central tendencies or preferred states. The grid states that constitute attractors represent the more central, stable, salient processes (IMs) and contents (protonarratives) of Caroline's therapy in each session.

The attractors (combinations of protonarrative and the IMs) that were identified in Caroline's case are pinpointed with squares in Figure $\mathrm{V}$ and summarized in Table III. It was possible to identify attractors in all of the sessions. Every protonarrative and three of the five IM types (action, reflection, and reconceptualization) participated in attractors in some session. Optimism was associated with reflection and reconceptualization IMs, achievement with both action and reflection IMs, and balance with reconceptualization IMs only.

The evolution of attractors across sessions seemed to show an initial period (Session 2-5) of rigidity and stability of the optimism protonarrative expressed in reflection IMs. That is, alternative meanings to the problematic self-narrative emerged initially in straight opposition to it and in the form of reflection IMs.

This was followed by a period of expansion of attractors, with the emergence of the third protonarrative in Session 6 (Balance $\times$ Reconceptualization) and by the simultaneous presence of the three protonarratives in Session 7 (Optimism $\times$ Reflection, Achievement $\times$ Action and Reflection, and Balance $\times$ Reflection).

Session 8 was marked by the return to the initial pattern optimism expressed in reflection IMs. In this session, Caroline narrated episodes in which she was optimistic in the past, that is, she reflected about how she used to manage her difficulties.

Sessions 9 and 10 involved different attractors. In Session 9, achievement was expressed in action and reflection IMs (similarly to Session 7), in the form of several cycles of action and reflection or, inversely, of reflection and action, demonstrated by the recurrent transitions between these two types (see Figure V). Balance was expressed in reconceptualization IMs, as Caroline described episodes in which she was able to take action to manage her difficulties and reflected about the meaning of these actions. Session 10's attractors returned to the optimism protonarrative expressed in reflection and reconceptualization IMs, as Caroline described being optimistic in the past regarding how she used to manage her difficulties (reflection IMs), overcoming pessimism and looking at herself from an optimistic standpoint (reconceptualization IMs).

The last session (Session 12) was characterized by balance expressed in reconceptualization IMs. This was technically a contraction, given that the attractor included only one protonarrative and one IM type; however, in contrast with previous moments of contraction, meanings inconsistent with the attractor's theme (optimism and achievement) and narrative processes (action, reflection, protest and performing change) were also present (see Figure V). In effect, 

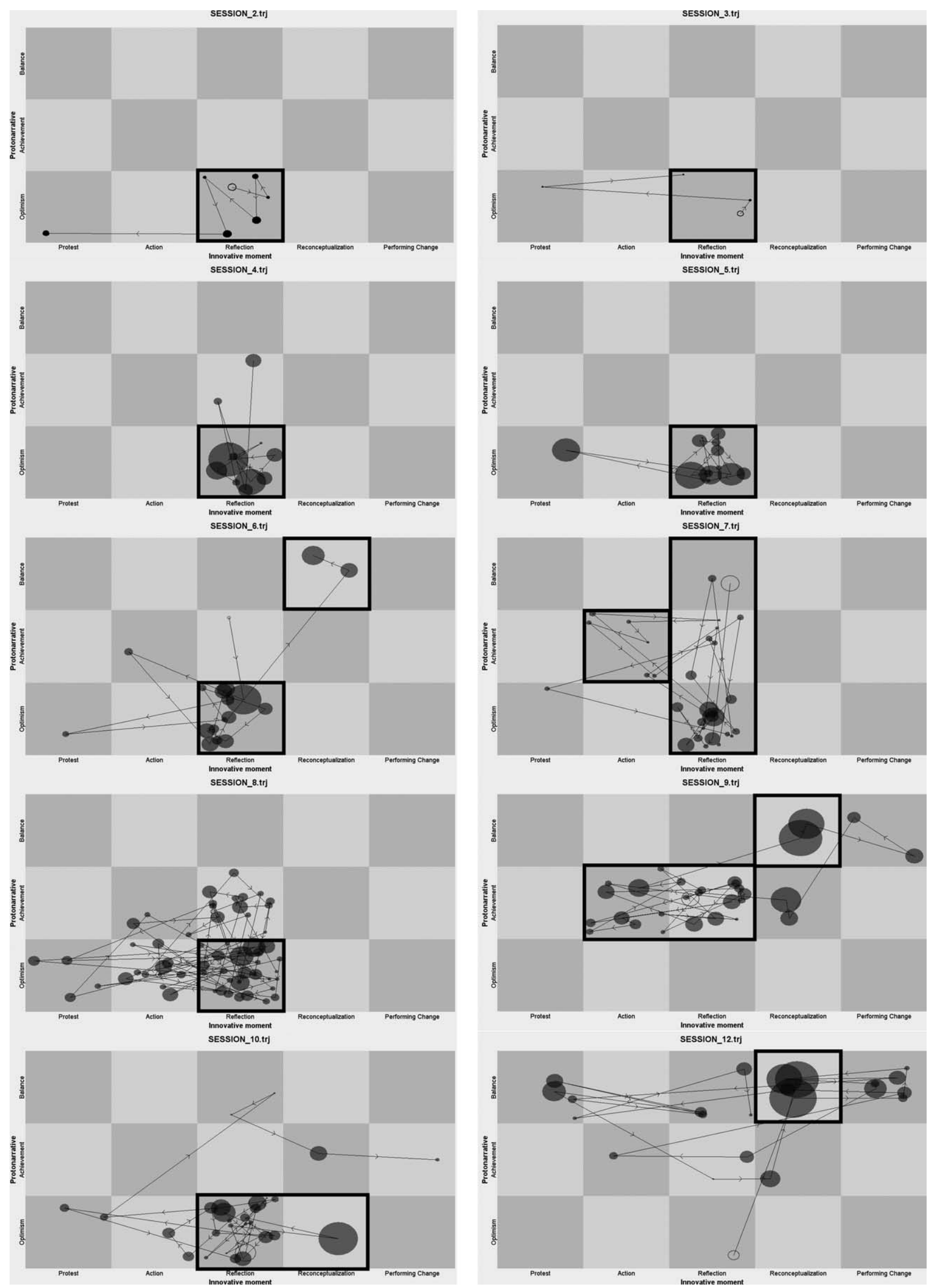

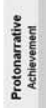

Figure V. SSGs for Carolines therapy. 
Table III. Summary of Attractors

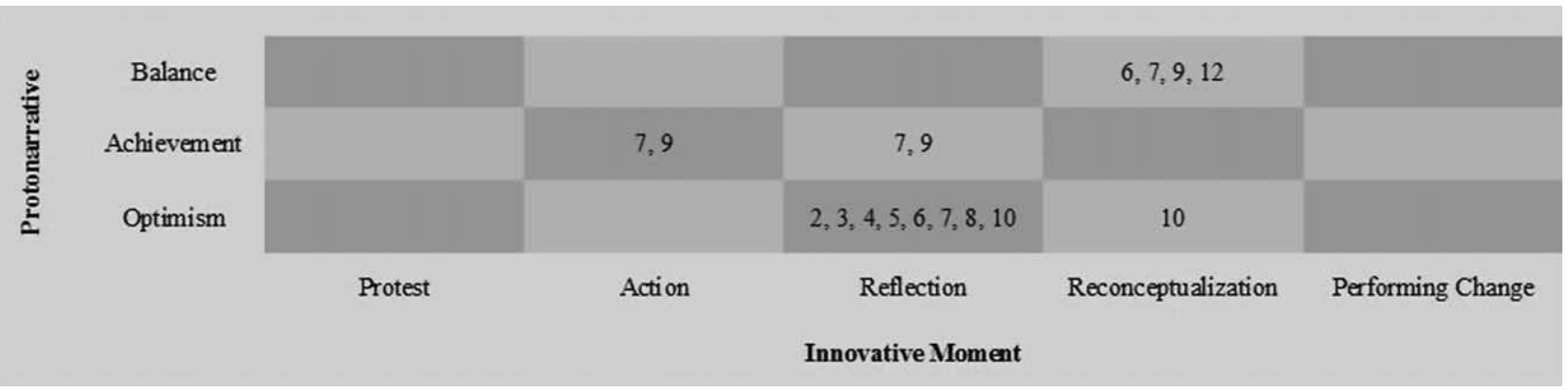

Note. Numbers inside cells represent sessions in which that cell was an attractor cell.

the characteristics of final sessions seemed to correspond to the theoretical characteristics that have been attributed to alternative self-narratives, that is, its flexibility. Globally, attractors changed throughout Caroline's therapy, with periods of increased and constant change intermediated by returns to the narrative processes and meanings that were characteristic of the beginning of the therapy.

In contrast to the other protonarratives, the achievement protonarrative never constituted a central theme of Caroline's therapy on its own; it appeared as a nuclear content only when associated with other protonarratives. Perhaps it represented a transition between the initial organizing protonarrative (optimism) and the final organizing protonarrative (balance). It is also interesting that the more complex protonarrative (balance) was strictly associated with reconceptualization IMs, which is a central IM in the change process according to our change model (see Figure 1).

\section{How Does the Flexibility of the Alternative Self-Narrative Evolve Across Sessions?}

Finally, we focused on the evolution of the alternative self-narrative across Caroline's therapy. A dynamic system's flexibility has been considered to be a function of its dispersion (Granic et al., 2007; Hollenstein \& Lewis, 2006). Dispersion is a composite measure of the range and duration of states of the system. It incorporates duration of each type of IM, total duration of protonarratives, and number of IM types according to the formula

$$
\left[\left(n \sum\left(d_{i} / D\right)^{1}\right)-1\right] / n-1 .
$$

In SSGs, $d_{i}$ is duration in cell $i, D$ is total duration of the visited cells, and $n$ is the number of cells visited. This measure is directly calculated by GridWare and varies between 0 and 1 . Low values mean low range and duration of system states and indicate low overall dispersion. Because dispersion combines both duration and number of states, fluctuations in dispersion may reflect changes in either protonarrative duration or the number of types of IMs that express them.

As shown in Figure VI, overall flexibility increased from Sessions 4 to 9 and stabilized in the last sessions at a higher level. That is, across these sessions, the number of IM types and protonarratives that were simultaneously present increased, and the time spent on them tended to be similarly distributed across all of them. This increasing overall flexibility across sessions reflected a progressive expansion of protonarratives and IM types (see Figure V). In other words, the process by which problematic self-narratives gave way to alternative self-narratives seemed to be characterized by an increase in flexibility. Psychologically, the meanings that organized the new protonarrative (balance) were less rigid than the ones that organized the protonarrative at the beginning of the therapy (optimism).

\section{Discussion}

The analysis of protonarratives using SSGs shed light on how IMs contributed to the reconstruction of Caroline's self-narrative. First, our observations were consistent with the IMs heuristic model of change (M. M. Gonçalves et al., 2009). In particular, IM salience and diversity increased throughout therapy, and reflection, protest, and action IMs were prevalent in the initial and intermediate phases,

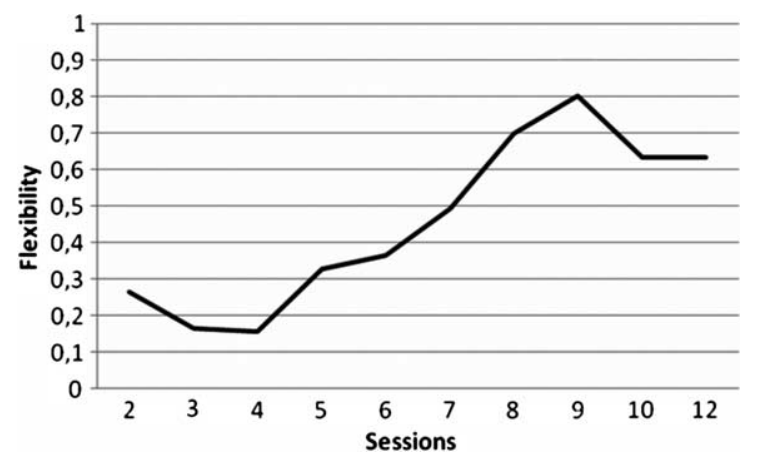

Figure VI. Overall flexibility across sessions. 
whereas reconceptualization and performing change IMs were prevalent in the final phase. Second, this study's observations helped us to refine and extend the model of change.

1. There was an increase in the diversity of innovative narrative contents or protonarratives throughout therapy, which corroborates our core premise. Globally, flexibility of the meaning processes increased throughout therapy.

2. There was a progressive integration of the problem in the emergent protonarratives. The relation between the previous narrative rule and the new narrative rule evolved from opposition (optimism) to an empowered relation (achievement) to assimilation (balance). It might be sensible to think of the three identified protonarratives as elements or stages in the development of a single alternative self-narrative rather than as independent potential self-narratives.

3. This process is seemingly facilitated by different types of IMs, which play an organizing role in protonarratives' emergence and development. Initially, reflection IMs (optimism) seem to enhance Caroline's understanding of how pessimism constrained her life and also to consolidate hope. Later, cycles of action and reflection IMs (or, inversely, reflection and action, i.e., achievement) seem to facilitate self-confidence and empowerment. Finally, reconceptualization IMs (balance) seem to represent the achievement of what has been called a "meaning bridge" within the assimilation model (Brinegar, Salvi, Stiles, \& Greenberg, 2006; Osatuke et al., 2004; Stiles, 1999, 2002). A meaning bridge is a sign (a word, phrase, story, theory, image, gesture, or other expression) that represents the same meaning for divergent parts of the self (in this case, pessimism and optimism). The "balance" meaning bridge seemed to assimilate a wider range of Caroline's experiences, allowing the varied parts of her to communicate smoothly with one another and engage in joint action. It thus allowed both pessimism and optimism to serve as resources. One may hypothesize that the more empowered relation to pessimism expressed by the achievement protonarrative might have facilitated the elaboration of the limitations of optimism (e.g., the potentially bad consequences of an overly optimistic perspective), therefore promoting a linkage between pessimism and optimism and consequently the inclusion of pessimism in a more balanced narrative trend (i.e., balance).

4. Attractors seemed to change throughout therapy, with periods of increased change countered by a return to processes that were characteristic of the beginning of therapy. This process seems congruent with Fogel, Garvey, Hsu, and West-Stroming's (2006) suggestion, referring to changing patterns in early mother-baby interaction, that the "return to the past" for brief periods seems to stabilize the system during developmental change, regulating the "potentially chaotic effect of reorganization" (p. 66). This finding is certainly interesting but merits much more empirical research, although it intuitively makes sense: When disturbed by the novelty, the system can find some stability by returning temporarily to previous patterns of functioning. Alternatively, the apparent setbacks might reflect turning attention to newer, less developed strands of the problematic self-narrative (Caro Gabalda \& Stiles, 2009, submitted). Furthermore, Caroline's alternative self-narrative, at the last session, was structured enough to constitute an organizer framework, that is, an attractor composed by a central theme (balance) and narrative process (reconceptualization) but nevertheless more flexible (i.e., open to other meanings inconsistent to its theme [optimism and achievement] and narrative processes [action, reflection, protest, and performing change]).

We conclude that studying the emergence of protonarratives makes IMCS content sensitive and, therefore, enriches its analysis.

\section{Limitations and Implications}

Although we presented only one case, it would be misleading to say that " $N=1$." Rather, this was a theory-building case study (Stiles, 2005, 2009), in which we presented a substantial number of theoretically relevant quantitative and qualitative observations that supported and elaborated previous conceptualizations. That said, other cases are likely to differ from Caroline in important ways, so, of course, more research is needed. Among other things, Caroline presented relatively simple clinical complaints. Other, more disturbed clients might present different or more complex patterns of protonarrative evolution.

Conceptually, our observations of Caroline's protonarratives suggest that they might represent a process of dialectical development. The three 
protonarratives (optimism, achievement, balance) seemed to represent a sequence of increasing integration, each one encompassing the previous ones as well as more aspects of the problematic self-narrative. This suggestion is congruent with the assimilation model's description of the construction of meaning bridges between different parts of the self, in which some metamorphosis in the successive versions is required to accommodate more aspects of initially conflicting parts (Brinegar et al., 2006; Stiles, 1999). It is similarly congruent with M. M. Gonçalves et al.'s (2009) proposal that reconceptualization IMs are essential in transforming self-narratives by articulating links between heterogeneous dimensions of the self or the self-narrative. It is consistent that Caroline's balance protonarrative was closely associated with reconceptualization IMs. Future researchers might usefully attend to whether successive protonarratives represent increasing assimilation of the client's disparate experiences or meanings and whether the more integrative protonarratives are differentially associated with reconceptualization IMs.

Clinically, increasing the flexibility of a client's system of meanings should facilitate change. Thus, as in the case of Caroline, we suggest that exploration of diverse protonarratives allows a client to construct more viable alternatives, a favorable element of the change process. Therapists-in-training might profitably learn to recognize alternative protonarratives and IMs as they emerge during treatment.

\section{Acknowledgements}

This article was supported by Portuguese Foundation for Science and Technology Grants PTDC/PSI/ 72846/2006 (Narrative Processes in Psychotherapy, 2007-2010) and PhD Grants SFRH/BD/46189/ 2008 and SFRH/BD/48266/2008. We gratefully acknowledge the contribution of Jaan Valsiner, who critiqued earlier drafts of this article and assisted in the development of the concepts present herein, and extend our thanks to Eugénia Ribeiro and Joana Senra for allowing us to analyze the videos of Caroline's case.

\section{Note}

1 Other authors have used "protonarrative" in other ways. For instance, Salvatore, Dimaggio, and Semerari (2004) defined it as "micro-sequences of mental images continuously occupying our consciousness" (p. 236). Therapy may help clients to focus on these preexisting but unarticulated conscious elements of their life (protonarratives in Salvatore et al.'s sense) until they become fully fledged ones: IMs.

\section{References}

American Psychiatric Association. (1994). Diagnostic and statistical manual of mental disorders (4th ed.). Washington, DC: Author.

Angus, L., Levitt, H. \& Hardtke, K. (1999). The narrative processes coding system: Research applications and implications for psychotherapy practice. Fournal of Clinical Psychology, 55, 1255-1270.

Barkham, M., Stiles, W. B., \& Shapiro, D. A. (1993). The shape of change in psychotherapy: Longitudinal assessment of personal problems. Fournal of Consulting and Clinical Psychology, 61, 667677.

Brinegar, M. G., Salvi, L. M., Stiles, W. B., \& Greenberg, L. S. (2006). Building a meaning bridge: Therapeutic progress from problem formulation to understanding. Fournal of Counseling Psychology, 53, 165-180.

Bruner, J. (1986). Actual minds, possible worlds. Cambridge, MA: Harvard University Press.

Caro Gabalda, I., \& Stiles, W. B. (2009). Retrocessos no contexto de terapia linguística de avaliação [Setbacks in the context of linguistic therapy of evaluation]. Análise Psicológica, 27, 199212.

Caro Gabalda, I., \& Stiles, W. B. (submitted). Irregular assimilation progress: Setbacks in the context of linguistic therapy of evaluation. Manuscript submitted for publication.

Dimaggio, G., Salvatore, G., Azzara, C., \& Catania, D. (2003). Rewriting self-narratives: The therapeutic process. fournal of Constructivist Psychology, 16, 155-181.

Dimaggio, G., Salvatore, G., Azzara, C., Catania, D., Semerari, A., \& Hermans, H. J. M. (2003). Dialogical relationships in impoverished narratives: From theory to clinical practice. Psychology and Psychotherapy: Theory, Research and Practice, 76, 385-409.

Dishion, T., Nelson, S., Winter, C., \& Bullock, B. (2004). Adolescent friendship as a dynamic system: Entropy and deviance in the etiology and course of male antisocial behavior. fournal of Abnormal Child Psychology, 32, 651-663.

Fassinger, R. (2005). Paradigms, praxis, problems, and promise: Grounded theory in counseling psychology research. fournal of Counseling Psychology, 52, 156-166.

Fernandes, E. (2007). When what I wish makes me worse ... to make the coherence flexible. Psychology and Psychotherapy: Theory, Research and Practice, 80, 165-180.

Fernandes, E., Senra, J., \& Feixas, G. (2009). Terapia construtivista centrada em dilemas implicativos [Constructivist psychotherapy focused on implicative dilemmas]. Braga, Portugal: Psiquilíbrios.

Fogel, A., Garvey, A., Hsu, H. C., \& West-Stroming, D. (2006). Change processes in relationships: A relational-historical approach. New York: Cambridge University Press.

Gardner, B., \& Wampler, K. (2008). Uncovering dynamical properties in the emotional system of married couples. Contemporary Family Therapy, 30, 111-126.

Gonçalves, M. M., Matos, M., \& Santos, A. (2009). Narrative therapy and the nature of "innovative moments" in the construction of change. Fournal of Constructivist Psychology, 22, 1-23.

Gonçalves, M. M., Mendes, I., Cruz, G., Ribeiro, A. P., Angus, L., \& Greenberg, L. S. (2010). Narrative change in clientcentered therapy: A comparison of innovative moments development with emotion-focused therapy. Manuscript in preparation.

Gonçalves, M. M., Mendes, I., Ribeiro, A. P., Angus, L., \& Greenberg, L. S. (2010). Innovative moments and change in emotion-focused therapy: The case of Lisa. fournal of Constructivist Psychology, 23, 267-294.

Gonçalves, M. M., Ribeiro, A. P., Matos, M., Mendes, I., \& Santos, A. (2010a). Tracking novelties in psychotherapy research 
process: The innovative moment coding system. Manuscript in preparation.

Gonçalves, M. M., Ribeiro, A. P., Matos, M., Mendes, I., \& Santos, A. (2010b). The innovative moments coding system: A new coding procedure for tracking changes in psychotherapy. In S. Salvatore, J. Valsiner, J. T. Simon, \& A. Gennaro (Eds.), YIS: Yearbook of idiographic science. Volume 2 (pp. 107-130). Rome: Firera \& Liuzo.

Gonçalves, M. M., Santos, A., Salgado, J., Matos, M., Mendes, I., Ribeiro, A. P., et al. (2010). Innovations in psychotherapy: Tracking the narrative construction of change. In J. D. Raskin, S. K. Bridges, \& R. Neimeyer (Eds.), Studies in meaning 4: Constructivist perspectives on theory, practice, and social justice (pp. 29-64). New York: Pace University Press.

Gonçalves, O. F., \& Machado, P. P. P. (1999). Narrative in psychotherapy: The emerging metaphor. Fournal of Clinical Psychology, 55, 1175-1177.

Granic, I., \& Hollenstein, T. (2003). Dynamic systems methods for models of developmental psychopathology. Development and Psychopathology, 15, 641-669.

Granic, I., Hollenstein, T., Dishion, T. J., \& Patterson, G. R. (2003). Longitudinal analysis of flexibility and reorganization in early adolescence: A dynamic systems study of family interactions. Developmental Psychology, 39, 606-617.

Granic, I., \& Lamey, A. (2002). Combining dynamic systems and multivariate analyses to compare the mother-child interactions of externalizing subtypes. Fournal of Abnormal Child Psychology, $30,265-283$.

Granic, I., O’Hara, A., Pepler, D., \& Lewis, M. D. (2007). A dynamic systems analysis of parent-child changes associated with successful "real-world" interventions for aggressive children. Fournal of Abnormal Child Psychology, 35, 845-857.

Hayes, A. M., Laurenceau, J.-P., Feldman, G. C., Strauss, J. L., \& Cardaciotto, L. A. (2007). Change is not always linear: The study of nonlinear and discontinuous patterns of change in psychotherapy. Clinical Psychology Review, 27, 715-723.

Hermans, H. J. M., \& Hermans-Jansen, E. (1995). Self-narratives: The construction of meaning in psychotherapy. New York: Guilford Press.

Hill, C. E., Knox, S., Thompson, B. J., Nutt Williams, E., Hess, S. A., \& Ladany, N. (2005). Consensual qualitative research: An update. Fournal of Counseling Psychology, 52, 196-205.

Hill, C. E., \& Lambert, M. J. (2004). Methodological issues in studying psychotherapy processes and outcomes. In M. J. Lambert (Ed.), Bergin and Garfield's handbook of psychotherapy and behavior change (5th ed., pp. 84-135). New York: Wiley.

Hollenstein, T. (2007). State space grids: Analyzing dynamics across development. International fournal of Behavioral Development, 31, 384-396.

Hollenstein, T., Granic, I., Stoolmiller, M., \& Snyder, J. (2004). Rigidity in parent-child interactions and the development of externalizing and internalizing behavior in early childhood. Fournal of Abnormal Child Psychology, 32, 595-607.

Hollenstein, T., \& Lewis, M. (2006). A state space analysis of emotion and flexibility in parent-child interactions. Emotion, 6, 656-662.

Jacobson, N. S., \& Truax, P. (1991). Clinical significance: A statistical approach to defining meaningful change in psychotherapy research. Fournal of Consulting and Clinical Psychology, 59, 12-19.

Lambert, M. J., Burlingame, G. M., Umphress, V., Hansen, N. B., Vermeersch, D. A., Clouse, G. C., et al. (1996). The reliability and validity of the Outcome Questionnaire. Clinical Psychology and Psychotherapy, 3, 249-258.

Lamey, A., Hollenstein, T., Lewis, M. D., \& Granic, I. (2004). GridWare (Version 1.1) [Computer software]. Retrieved from http://statespacegrids.org.
Lewis, M. D., Lamey, A. V., \& Douglas, L. (1999). A new dynamic systems method for the analysis of early socioemotional development. Developmental Science, 2, 458-476.

Lewis, M. D., Zimmerman, S., Hollenstein, T., \& Lamey, A. V. (2004). Reorganization in coping behavior at $1 \frac{1 / 2}{2}$ years: Dynamic systems and normative change. Developmental Science, 7, 56-73.

Machado, P. P. P., \& Fassnacht, D. (in preparation). The Outcome Questionnaire (OQ-45) in a Portuguese population: Psychometric properties, ANOVAS, and confirmatory factor analysis. Manuscript in preparation.

Machado, P. P. P., \& Klein J. (2006, June). Outcome Questionnaire45: Portuguese psychometric data with a non-clinical sample. Poster presented at the 37th Annual Meeting of the Society for Psychotherapy Research, Edinburgh, Scotland.

Martin, C., Fables, R., Hanish, L., \& Hollenstein, T. (2005). Social dynamics in the preschool. Developmental Review, 25, 299-327.

Matos, M., Santos, A., Gonçalves, M. M., \& Martins, C. (2009). Innovative moments and change in narrative therapy. Psychotherapy Research, 19, 68-80.

McAdams, D. P. (1993). The stories we live by: Personal myths and the making of the self. New York: William Morrow.

McGlinchey, J. B., Atkins, D. C., \& Jacobson, N. S. (2002). Clinical significance methods: Which one to use and how useful are they? Behavior Therapy, 33, 529-550.

Mendes, I., Ribeiro, A. P., Angus, L., Greenberg, L., Sousa, I., \& Gonçalves, M. M. (in press). Innovative moments and change in emotion-focused therapy. Psychotherapy Research.

Morrow, S. L. (2005). Quality and trustworthiness in qualitative research in counseling psychology. Fournal of Counseling Psychology, 52, 250-260.

Neimeyer, R. A. (1995). Client-generated narratives in psychotherapy. In R. A. Neimeyer \& M. J. Mahoney (Eds.), Constructivism in psychotherapy (pp. 231-246). Washington, DC: American Psychological Association.

Neimeyer, R. A., Herrero, O., \& Botella, L. (2006). Chaos to coherence: Psychotherapeutic integration of traumatic loss. Fournal of Constructivist Psychology, 19, 127-145.

Osatuke, K., Glick, M. J., Gray, M. A., Reynolds, D. J., Jr., Humphreys, C. L., Salvi, L. M., et al. (2004). Assimilation and narrative: Stories as meaning bridges. In L. Angus \& J. McLeod (Eds.), Handbook of narrative and psychotherapy: Practice, theory, and research (pp. 193-210). Thousand Oaks, CA: Sage.

Polkinghorne, D. E. (1988). Narrative knowing and the human sciences. Albany: State University of New York Press.

Ribeiro, A. P., Bento, T., Gonçalves, M. M., \& Salgado, J. (2010). Commentary: Self-narrative reconstruction in psychotherapy: Looking at different levels of narrative development. Culture $\mathbb{E}$ Psychology, 16, 195-212.

Ribeiro, A. P., Gonçalves, M. M., \& Ribeiro, E. (2009). Processos narrativos de mudança em psicoterapia: Estudo de um caso de sucesso de terapia construtivista [Narrative change in psychotherapy: A good-outcome case of constructivist therapy]. Psychologica, 50, 181-203.

Ribeiro, A., Gonçalves, M. M., \& Santos, A. (in press). Innovative moments in psychotherapy: From the narrative outputs to the semiotic-dialogical processes. In S. Salvatore, J. Valsiner, S. Strout, \& J. Clegg (Eds.), YIS: Yearbook of idiographic science. Volume 3. Rome: Firera \& Liuzo.

Salvatore, G., Dimaggio, G., \& Semerari, A. (2004). A model of narrative development: Implications for understanding psychopathology and guiding therapy. Psychology and Psychotherapy: Theory, Research and Practice, 77, 231-254.

Santos, A., Gonçalves, M. M., Matos, M., \& Salvatore, S. (2009). Innovative moments and change pathways: A good-outcome 
case of narrative therapy. Psychology and Psychotherapy: Theory, Research and Practice, 82, 449-466.

Santos, A., Gonçalves, M. M., \& Matos, M. (2010). Innovative moments and poor outcome in narrative therapy. Counselling and Psychotherapy Research. DOI: 10.1080/14733140903398 153.

Sarbin, T. R. (1986). The narrative and the root metaphor for psychology. In T. R. Sarbin (Ed.), Narrative psychology: The storied nature of human conduct (pp. 3-21). New York: Praeger.

Schielke, H. J., Fishman, J. L., Osatuke, K., \& Stiles, W. B. (2009). Creative consensus on interpretations of qualitative data: The Ward method. Psychotherapy Research, 19, 558-565.

Senra, J., Feixas, G., \& Fernandes, E. (2007). Manual de Intervención en Dilemas Implicativos [Manual of intervention in implicative dilemmas]. Revista de Psicoterapia, 63/64, 179201.

Senra, J., \& Ribeiro, E. (2009). The process of change in implicative dilemmas: The case of Rose. Manuscript in preparation.

Stiles, W. B. (1999). Signs and voices in psychotherapy. Psychotherapy Research, 9, 1-21.

Stiles, W. B. (2002). Assimilation of problematic experiences. In J. C. Norcross (Ed.), Psychotherapy relationships that work:
Therapist contributions and responsiveness to patients (pp. 357365). New York: Oxford University Press.

Stiles, W. B. (2003). Qualitative research: Evaluating the process and the product. In S. P. Llewelyn \& P. Kennedy (Eds.), Handbook of clinical health psychology (pp. 477-499). London: Wiley.

Stiles, W. B. (2005). Case studies. In J. C. Norcross, L. E. Beutler, \& R. F. Levant (Eds.), Evidence-based practices in mental health: Debate and dialogue on the fundamental questions (pp. 57-64). Washington, DC: American Psychological Association.

Stiles, W. B. (2009). Logical operations in theory-building case studies. Pragmatic Case Studies in Psychotherapy, 5, 9-22.

Thelen, E., \& Smith, L. B. (1998). Dynamic systems theories. In R. Lerner (Ed.), Handbook of child psychology, 5th edition: Vol. 1. Theoretical models of human development (pp. 563-633). New York: Wiley.

White, M. (2007). Maps of narrative practice. New York: Norton. White, M., \& Epston, D. (1990). Narrative means to therapeutic ends. New York: Norton. 